\title{
The determinants of visitor length of stay at the Kruger National Park
}

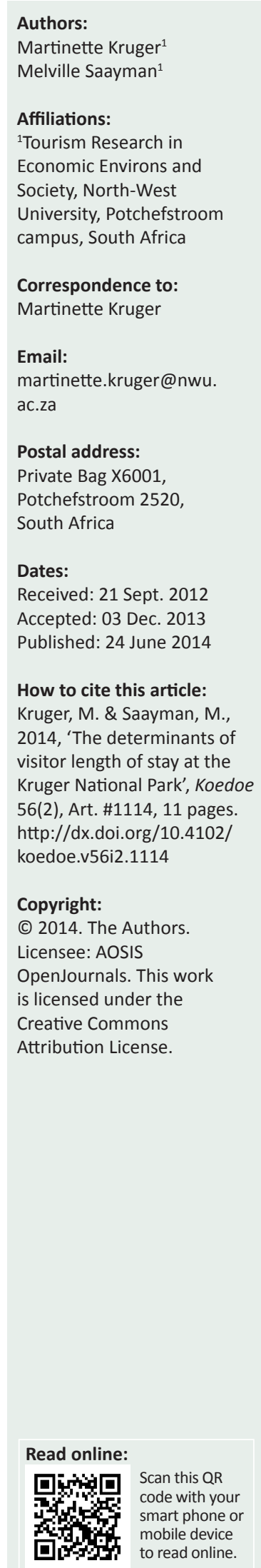

This study analysed the determinants of tourists' length of stay at one of South Africa's oldest and largest national parks, the Kruger National Park. It took the different regions of this Park into account and analysed visitors to the northern and southern regions separately to distinguish the different determinants of length of stay. The results showed clear differences between the determinants of length of stay for the two regions, indicating that for a destination with the size and scope of the Kruger Park, a regional approach should be followed to improve management and encourage visitors to stay longer.

Conservation implications: The northern and southern regions of the Kruger National Park differ significantly in terms of ecosystems, rainfall, climate and wildlife. From a tourism perspective, these regions should be managed separately taking the distinct differences of the two regions into consideration. Different variables influence visitors' length of stay in these two regions. Conservation practitioners can use the results of this study to manage visitors to these areas.

\section{Introduction}

This study looked at what determines the length of time tourists stay at one of South Africa's oldest and largest national parks, the Kruger National Park. Menezes, Moniz and Vieira (2008:205) state that 'the overall impact of tourists in a given economy hinges on length of stay'. Length of stay is of fundamental importance for tourist destinations, because the tourist product adapts itself to the amount of time the tourist has available at the destination and promotional campaigns must also be adjusted to the tourist's decisions in this regard (Martinez-Garcia \& Raya 2008:1064). Thrane and Farstad (2009:2) and Barros, Butler and Correia (2010:13) agree that length of stay is of major importance to any tourism destination, because longer stays are positively associated with the total earnings from tourist activities and with higher bed-occupancy rates.

\section{Barros and Machado (2010) posit that:}

tourist destinations should aim to attract tourists who wish to stay longer, particularly during off-peak seasons, since tourists who visit only for short periods tend to stay centrally and visit only the major tourist attractions. (p. 2)

Longer-stay tourists, on the other hand, visit a wider range of attractions, explore more peripheral regions and generate more diverse economic, social and environmental impacts. Alegre and Pou (2006) point out that:

length of stay at a holiday destination, a basic characteristic of the holiday, has important repercussions for the tourist destination since it affects occupancy rates and final income derived from tourists (in other words, the economic impact and value of tourists). (p. 1352)

Identifying the factors that make tourists stay longer is therefore extremely beneficial to any destination seeking to increase visitor spending (Peypoch et al. 2011:1).

Given that the topic is so important, there were several strong motives for researching length of stay and for choosing the Kruger National Park as a case study. Firstly, Alegre and Pou (2006) claim that most studies on tourism demand fail to pay attention to length of stay, at least at a micro-economic level, where the researcher can control for individual heterogeneous behaviour. In addition, even though most tourism economists and managers agree that length of stay has a direct impact on spending (see Cannon \& Ford 2002; Jang, Bai \& O’Leary 2004; Kozak, Gokovali \& Bahar 2008; Mules 1998; Seaton \& Palmer 1997; Spotts \& Mahoney 1991; Taylor, Fletcher \& Clabaugh 1993, amongst others), little attention has been paid to this important topic (Decrop \& Snelders 2004; Gokovali, Bahar \& Kozak 2007:737). Secondly, the topic of tourists visiting a South African nature-based destination has not attracted more research thus far, despite the essential role these destinations 
play in tourism and conservation (Holden 2008:180; South African National Parks [SANParks] 2009:31). Thirdly, the huge numbers of visitors to the Kruger Park make it South Africa's most profitable national park (SANParks 2009:19).

As an all-inclusive holiday destination that provides a unique nature and leisure experience, the Kruger Park is a magnet for tourists, both domestic and international. It is a major export earner and constitutes an important part of the South African tourism industry (Cook, Yale \& Marqua 2010:212; Saayman \& Saayman 2008; Uysal, McDonald \& Martin 1994:18). The Park attracts over one million visitors per annum and is one of the top five international tourist destinations in the country (SANParks 2009; Van der Merwe \& Saayman 2008:154). Currently, $80 \%$ of SANParks revenue comes from Kruger Park accommodation and admission fees (Mabunda \& Wilson 2009:118). The findings of this study, a contribution to the still small literature on the topic, will be valuable in helping to sustain this growth and ensure long-term sustainability and competitiveness.

Finally, the size of the Kruger Park also makes it an ideal subject for this research, as it allows for comparison, within one park, of different tourist motives for length of stay. This is one of the largest game reserves in the world, covering approximately $20000 \mathrm{~km}^{2}$, and extending $350 \mathrm{~km}$ from north to south and $60 \mathrm{~km}$ from east to west; an area larger than, for example, Israel, Wales or the Netherlands. The Kruger Park includes two climatic transitional zones, namely the tropical and subtropical north and the temperate south; each with a clear rainfall gradient (lower rainfall in the south compared to the north) (Mabunda, Pienaar \& Verhoff 2003:16). From an ecological point of view, it is divided into four regions, namely the far northern and northern (Shingwedzi, Pafuri and Punda Maria), central (Mopani, Satara, Orpen and Letaba) and southern (Berg-en-Dal, Crocodile Bridge, Pretoriuskop, Biyamiti, Malelane and Lower Sabie) (see Figure 1), each with its diverse ecosystem, vegetation and wildlife. From a tourism perspective, it is divided into northern and southern regions and tourists are attracted to these regions for different reasons, depending on what they want to see and do. Notable differences between the two regions include the number of rest camps and accommodation available (e.g. the southern region has more rest camps), accessibility (e.g. certain parts of the northern region are only accessible by $4 \times 4 \mathrm{~s}$ and there are fewer entry gates to this region), as well as wildlife and vegetation found (e.g. owing to a higher vegetative biomass to game ratio, the central and southern regions have more game and are known for sightings of the Big Five, whilst the northern region is more known for its large hippo, elephant and wild dog populations) (SA Venues 2013; Smit, Grant \& Whyte 2007:227; Tinker \& Tinker 2011:4).

Tourists' length of stay in the Kruger Park, and consequently the determinants thereof, will therefore depend on their specific choices. Taking this into consideration, this study analysed the northern and southern tourists separately so as to distinguish between the different determinants. The results of the analysis made it possible to propose strategies to increase the amount of time tourists spend in the Kruger Park.

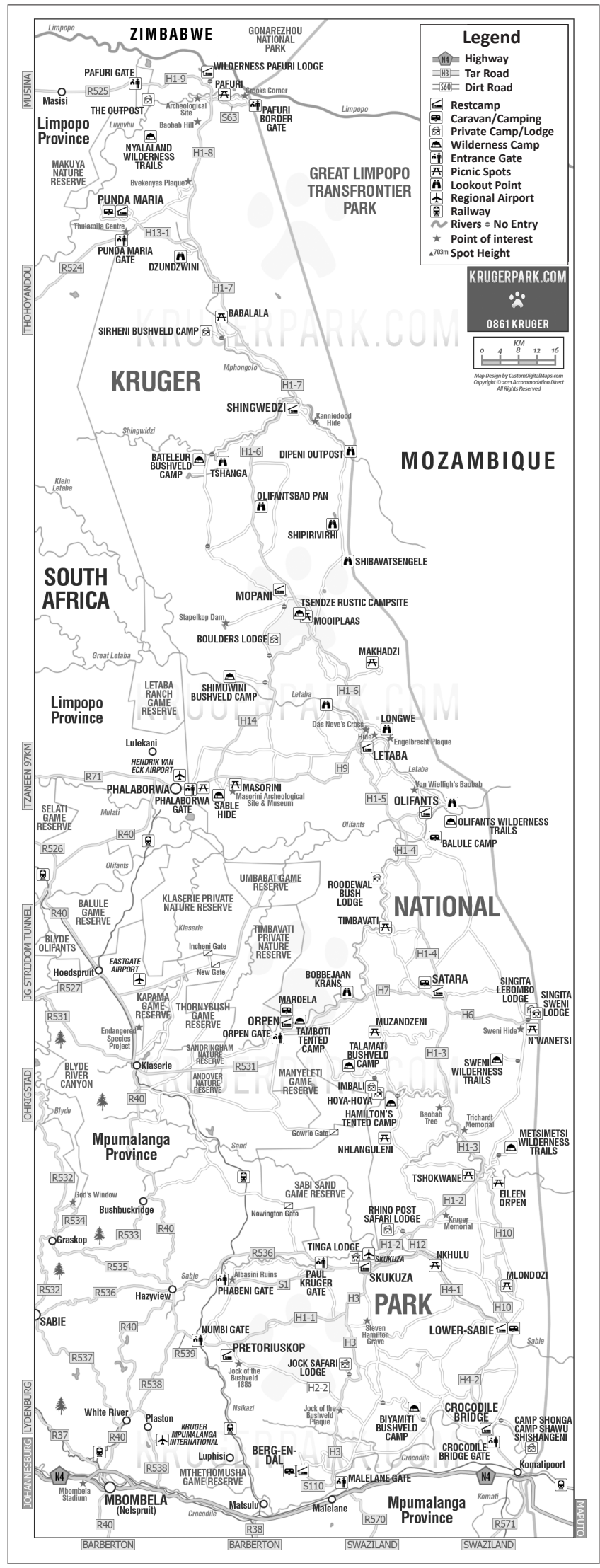

Source: Krugerpark.com, 2011, Full map of the Kruger National Park, viewed 07 August 2013, from http://www.krugerpark.com/maps/full-map-of-the-kruger-national-park/ FIGURE 1: Map of the Kruger National Park. 


\section{Literature review}

How long to spend on a visit is one of the main considerations in peoples' decision-making processes when making holiday plans, so destination managers need to know how to intervene in this process so as to encourage them to stay longer and thus spend more (Alegre \& Pou 2006; Peypoch et al. 2011). Tourists weigh up the benefits of different holiday destinations, assessing the cost of each and the length of stay they can afford, financially and time-wise (Alegre \& Pou 2006:1343). The chosen length of stay may reflect the attractiveness of a destination, but several other factors may come into play, as Gokovali et al. (2007) indicate:

the amount of free time the tourist has available, the availability of flexible package tour deals, the level of prices, the number of people in the party, and familiarity with the destination, to name but a few. (p. 737)

The length of a holiday, like the decision to take a trip or the choice of a particular destination, may therefore be explained by a combination of internal and external factors, as shown in Figure 2. Internal factors may be personal and family characteristics, as well as economic factors such as the tourist's level of income (Alegre \& Pou 2006; Machado 2010). External variables may include destination-specific (in this case park-specific) attributes such as destination image, type of destination, activities and amenities on offer or the price of the holiday (Saayman \& Saayman 1997; Machado 2010; Kruger et al. 2012).

Once the combination of factors that influence length of stay have been determined, marketing strategies can be planned that will encourage longer stays at a destination so that economic benefits can be maximised (Barros \& Machado 2010:2; Gokovali et al. 2007:737; Menezes et al. 2008:206). Menezes et al. (2008) state that:

uncovering the determinants of length of stay is critical to the design of marketing policies that promote longer stays, associated with higher occupancy rates and revenue streams: an enterprise ever more valuable given the increasingly pervasive pattern of shorter length of stays. (p. 207)

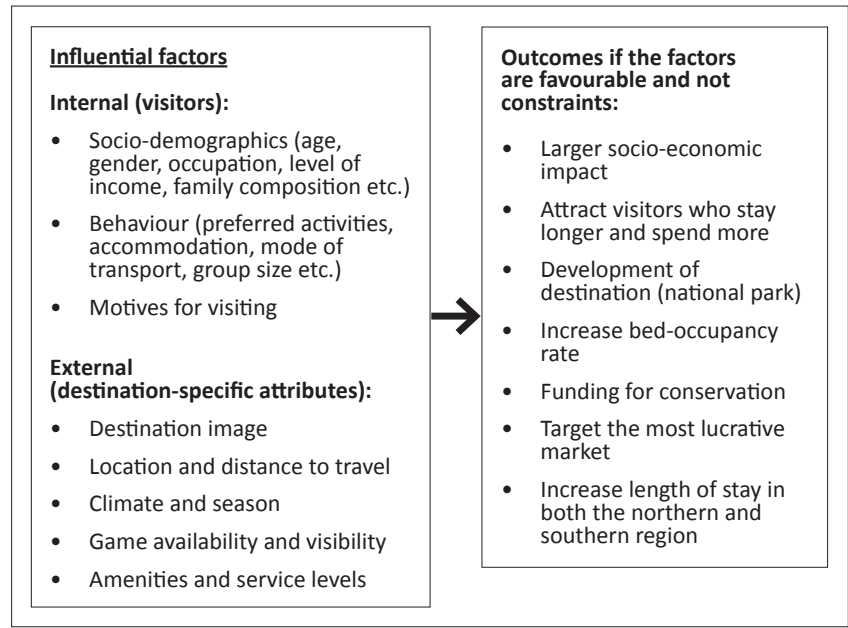

Source: Saayman and Saayman (1997) and Machado (2010). For more information on these sources, please see the reference list of the article, Kruger, M. \& Saayman, M., 2014, 'The determinants of visitor length of stay at the Kruger National Park', Koedoe 56(2), Art. \#1114, 11 pages. http://dx.doi.org/10.4102/koedoe.v56i2.1114

FIGURE 2: Factors influencing visitors' length of stay at a destination (national park).
Length of stay can also be an indicator of the profile of tourists visiting a particular destination and their propensity to spend whilst on holiday; information regarding their length of stay can consequently be used to increase tourist spending (Davies 2002; Gokovali et al. 2007; Legohérel 1998; Mok \& Iverson 2000).

Taking the length of stay into account can help in the effective management and planning of tourism destinations (Barros \& Machado 2010; Ritchie \& Crouch 2003). Visitors who stay longer experience more and the destination earns more as they are more likely to become aware of and use facilities and services at the location where they are staying and in surrounding regions (Gokovali et al. 2007; Kozak 2001). Saarinen (2005) points out that identifying the determinants of length of stay is important for research on sustainable tourism because:

they are useful in forecasting tourists' on-site time and, concomitantly, the stress on local resources caused by tourism activity; an important issue for analysing carrying capacity, especially at nature-based tourism destinations such as the Kruger Park. (p. 35)

However, despite the numerous benefits associated with identifying the determinants of length of stay, studies of this variable in tourism are rare (Barros \& Machado 2010:3), especially within a nature-based context. Those available are mainly descriptive - mostly of popular 'sea-and-sun' destinations - and they analyse the way different tourist profiles or types of trip affect the length of stay (see Alegre \& Pou 2006; Barros \& Machado 2010; Barros et al. 2010; Gokovali et al. 2007; Menezes et al. 2008; Martinez-Garcia \& Raya 2008; Oppermann 1995, 1997; Seaton \& Palmer 1997; Sung et al. 2001).

With regard to socio-demographic determinants, collectively these studies found that older, male and married tourists tend to stay longer at a destination than tourists with a higher level of education and a high-income profession (Alegre \& Pou 2006:1349-1352; Alegre, Mateo \& Pou 2011; Barros \& Machado 2010:10-13; Barros et al. 2010:18-20; Gokovali et al. 2007:742-744; Martinez-Garcia \& Raya 2008:1070-1073; Menezes et al. 2008:214-218; Peypoch et al. 2011). Some specific findings were that visitors aged 25-34 years had a lower probability of long stays than those aged 35-44 years (Gokovali et al. 2007:742-744) and that as the size of the party and daily expenditure increased, the probability of staying longer decreased (Alegre \& Pou 2006:1349-1352). Based on this, the following hypothesis was formulated:

- Hypothesis 1 (socio-demographic characteristics): The length of stay is determined by individual sociodemographic characteristics such as home language, marital status, level of education, annual gross income and province of origin.

With regard to behavioural determinants, studies show that tourists who travel shorter distances stay a shorter time than those who travel longer distances. Travel motives 
(leisure, visiting friends or relatives, business and others), repeat visits and an increased number of tourist attractions visited all increased the expected length of stay (Menezes \& Moniz 2006:10-12; Menezes et al. 2008:214-218). Gokovali et al. (2007:742-744) found that tourists who choose an 'allinclusive' type of holiday tend to have a lower probability of a long stay than those who choose a 'half-board' type of accommodation and that as the number of previous visits to the destination increases, the probability of a long stay increases; however, as the daily expenditure increases, the probability of a long stay decreases. When it comes to a destination's image, Machado (2010) reveals that tourists visiting destinations with a better reputation tend to stay longer. Other determinants, such as nationality, type of flight, environmental initiatives, repeat visits, word-ofmouth recommendations, as well as quality and hospitality also tend to encourage longer stays (Alegre \& Pou 2006: 1349-1352, 2011; Barros \& Machado 2010:10-13; Gokovali et al. 2007:742-744; Menezes \& Moniz 2006:10-12; Menezes et al. 2008:214-218; Peypoch et al. 2011). Based on this, the second hypothesis was formulated:

- Hypothesis 2 (behavioural characteristics): The length of stay is determined by individual behavioural characteristics such as mode of transport and travel motives.

The findings of the abovementioned studies show collectively that determinants of length of stay are destination specific, but that tourists' socio-demographic characteristics and economic factors are also significant determinants. Furthermore, it is important to note that tourists cannot be considered homogeneous in terms of the effects of different factors on how long they decide to stay. Given the size of the Kruger Park and the variety of its offerings, the determinants could differ for tourists visiting the northern and southern regions. This led to the third hypothesis:

- Hypothesis 3 (destination characteristics): The length of stay is determined by the destination characteristics (northern and southern region of the Park - for example, seeing certain types of animals found in each region) experienced and valued by the tourist.

\section{Research method and design The questionnaire}

The questionnaire used during the two surveys (north and south) consisted of three sections: Section A captured the respondents' demographic details, including language, gender, age, race, and marital status, country of residence, province, highest qualification and occupation, whilst Section B captured economic information such as size of travel group, number of people paid for, the type of accommodation used, the number of nights spent at the Park, the number of visits over the last 3 years and spending dynamics. The spending questions were detailed by spending category, including entrance and conservation fee, accommodation, food and beverages, shopping, recreation and transport. Section C captured the respondents' reasons for visiting the
Park, where 12 items were listed and respondents were asked to rate the importance of each item on a five-point Likert scale of importance: 1 = not at all important, 2 = slightly important, $3=$ important, $4=$ very important and $5=$ extremely important (cf. Kruger, Saayman \& Manners 2012). This section also captured respondents' perception of the value of the Big Five (i.e. the five most difficult African animals to hunt on foot: lion, African elephant, Cape buffalo, leopard and rhinoceros). For the purpose of this research, the information from all three sections was included in the analyses.

\section{Sampling method and survey}

The survey sample consisted of respondents to this questionnaire, which was distributed to visitors staying in the Kruger Park from 24 June 2011 to 02 July 2011 (northern region, winter survey) and from 27 December 2011 to 04 January 2012 (southern region, summer survey). The rest camps surveyed for the northern region were Olifants, Letaba, Mopani and Punda Maria and for the southern region Satara, Skukuza, Lower Sabie and Berg-en-Dal. Fieldworkers distributed questionnaires in the evenings and collected the questionnaires later during the same evening or early the next morning. A convenience sampling method was followed and questionnaires were therefore distributed to available overnight visitors (camping and chalet). Only one questionnaire per group was allowed and only adults (18 years and above) were allowed to complete the questionnaire.

The latest available SANParks statistics for 2009 were used to calculate the proportion of responses that would constitute a representative sample. According to these statistics, $384249(N)$ tourists stayed for at least one night in the Park in 2009 (Stevens 2010). Furthermore, Du Plessis, Saayman and Erasmus (2010) state that the average travelling group of tourists to the Park was 3.4 persons. The total population $(N)$ was divided by 3.4 and this resulted in 112132 tourist groups $(N)$. The minimum number of completed questionnaires sufficient for this study would be 399 (Israel 2009). Of the total of 853 questionnaires collected in the two surveys, 410 had been fully completed, 175 from the northern region and 235 from the southern region. Only fully completed questionnaires were used in the analysis to ensure that the important socio-economic and behavioural variables were all included.

\section{Statistical analysis}

Microsoft Excel was used to capture the data and IBM SPSS Statistics 20 and R 2.14.1 to analyse it. The analysis was conducted in two stages. Firstly, data were captured in Microsoft Excel and analysed using SPSS (2013). Factor analyses were conducted to determine respondents' motives for travelling to the northern and southern regions of the Kruger National Park. To determine whether a factor analysis could have been conducted on the motivational data variables, the Barlett's test of spehricity and Kaiser-Meyer-Olkin (KMO) measure of sampling adequacy was performed on both the expectations, as well as the experience scales. According to 
Barlett (1954), a factor analysis is appropriate when the result of the Barlett test for sphericity indicates significance, in other words $p<0.05$. In agreement, Kaiser $(1970,1974)$ explains that the minimum value of the KMO (the measure of sampling adequacy) for a factor analysis to be performed should be 0.6 . In order to determine the smallest number of factors from the respective data variables, the pattern matrix of the principle component factoring extraction technique was applied. The Kaiser normalisation (eigenvalues above 1.0 or more) guided the decision on the amount of facto rs retained. To name the factors, according to Dancey and Reidy (2004:431), a decision should be made on how strong the factor loadings must be to be included in a factor, but this tends to be arbitrary and varies amongst authors. All items with a factor loading above 0.4 were considered as contributing to a factor and all with loadings lower than 0.4 as not correlating significantly with this factor (Steyn 2000). In addition, any item that cross-loaded onto two factors, with factor loadings greater than 0.4 , was categorised in the factor where interpretability was best. The internal consistency of each factor was also calculated by means of the reliability coefficient (Cronbach's alpha). Only reliability coefficients above 0.6 were considered as acceptable for the study because a reliability coefficient below 0.6 indicates that the scale has poor reliability and unsatisfactory internal consistency (Malhotra 2007:285; Zikmund et al. 2010:306). Additionally the inter-item correlations were also calculated as another reliability measure, which, as recommended by Briggs and Cheek (1986), should be between 0.2 and 0.4 .

Secondly, the dependent (predicted) variable was understood to be length of stay, defined as the number of days at the Park; accordingly, it is a non-negative count variable. A Poisson regression was applied to identify the determinants of length of stay for both the northern and southern region. The link function for a Poisson regression model is the log link function and the model (with a log link) used in this research is as follows:

$\log \mu=\alpha+\beta x$

[Eqn 1]

The mean satisfies the exponential relationship:

$\mu=\exp (\alpha+\beta x)=e^{\alpha}\left(e^{\beta}\right)^{x}$

Where:

a one-unit increase in $x$ has a multiplicative impact of $\mathrm{e}^{\beta}$ on $\mu$. The mean of $Y$ at $x+1$ equals the mean of $Y$ at $x$ multiplied by $e^{\beta}$. If $\beta=0$, then $e^{\beta}=e 0=1$ and the multiplicative factor is 1 . Then, the mean of $Y$ does not change as $x$ changes. If $\beta>0$, then $e^{\beta}>1$, and the mean of $Y$ increases as $x$ increases. If $\beta<0$, the mean decreases as $x$ increases. (Agresti 2007:75)

A Poisson regression model was also used to find the determinants of length of stay for the southern region; however, the over-dispersion parameter was 2.45. A negative binomial regression was used because this model takes this over-dispersion into account. According to Agresti (2007:81), the negative binomial is another distribution that is concentrated on the non-negative integers. Unlike the Poisson, it has an additional parameter such that the variance can exceed the mean. The negative binomial distribution has:

$E(Y)=\mu, \operatorname{Var}(Y)=\mu+D \mu^{2}$

The index $D$, which is non-negative, is called a dispersion parameter. The negative binomial distribution occurs as a type of mixture of Poisson distributions. Greater heterogeneity in the Poisson means results in a larger value of $D$. As $D \rightarrow 0$, $\operatorname{Var}(Y) \rightarrow \mu$ and the negative binomial distribution converges to the Poisson distribution. The further $D$ falls above 0 , the greater the over-dispersion relative to Poisson variability (Agresti 2007:81).

\section{Results}

This section presents the profile of respondents as well as the results of the factor analysis (travel motives), the Poisson regression analysis (northern region) and the negative binomial regression analysis (southern region).

\section{Profile of respondents}

Table 1 shows the profile of the respondents in each of the two regions surveyed in 2011-2012. There are notable similarities between the northern and southern region tourists, especially in terms of home language, average age, marital status, level of education, mode of transport, length of stay and being holders of a Wild Card (a loyalty card that can be used at all 22 national parks in South Africa and offers the benefits of discounted entrance fees and a contribution to conservation). The main differences between the two profiles are in terms of province of origin, average spending and financial responsibility, with the northern region attracting more visitors from the Western Cape, who are financially responsible for more people during their trip and, consequently, have a higher average spending than tourists who visit the southern region.

\section{Factor analysis}

The pattern matrix of the principal component factor analyses using an Oblimin rotation with Kaiser normalisation identified four motivational factors each for the northern and the southern regions. These were labelled according to similar component items (Table 2). These factors accounted for $58 \%$ and $64 \%$ of the total variance for north and south, respectively. The average of all items contributing to a specific factor revealed factor scores that interpret the factor to the original five-point Likert scale. All factors indicated very good convergent validity with Cronbach alphas above 0.6 and inter-item correlations of between 0.31 and 0.63 .

In the case of the northern region, 'to photograph animals and plants' was not included in the factor analysis, because it did not have a loading greater than 0.4. The Kaiser-Meyer-Olkin measure of sampling adequacy of, respectively, 0.70 and 0.75 indicated that patterns of correlation were relatively compact and yielded distinct and reliable factors (Field 2005:640). In 
TABLE 1: Comparison of profiles of respondents staying in the northern and southern regions of the Kruger National Park, 2011-2012.

\begin{tabular}{|c|c|c|}
\hline Category & Respondents June-July 2011, northern region & Respondents December 2011 - January 2012, southern region \\
\hline Home language & Afrikaans (64\%); English (32\%) & Afrikaans (64\%); English (35\%) \\
\hline Average age & 49 years & 46 years \\
\hline Most common marital status & Married & Married \\
\hline National respondents' province of origin & Gauteng and Western Cape & Gauteng and Mpumalanga \\
\hline Majority of respondents' country of origin & South Africa $(92 \%)$ & South Africa $(88 \%)$ \\
\hline International respondents' country of origin & $\begin{array}{l}\text { United States of America, Australia, Germany, } \\
\text { Netherlands, United Kingdom }\end{array}$ & Germany, Netherlands, United Kingdom, France \\
\hline Highest level of education & Diploma or Degree & Diploma or Degree \\
\hline $\begin{array}{l}\text { Average number of people paid for (financial } \\
\text { responsibility during trip) }\end{array}$ & 4 persons & 3 persons \\
\hline Most common mode of transport & $4 \times 4$ and sedan & $4 \times 4$ and sedan \\
\hline Average length of stay & 6.2 nights & 6.3 nights \\
\hline Average expenditure per group & R 8884.00 & R 8208.00 \\
\hline In possession of a Wild Card & Yes & Yes \\
\hline
\end{tabular}

TABLE 2: Results of the factor analyses - motives of visitors to the Kruger National Park.

\begin{tabular}{|c|c|c|c|c|c|c|}
\hline Region & Motivation factors & Motivation items & $\begin{array}{l}\text { Factor } \\
\text { loadings }\end{array}$ & $\begin{array}{l}\text { Mean } \\
\text { value }\end{array}$ & $\begin{array}{l}\text { Reliability } \\
\text { coefficient }\end{array}$ & $\begin{array}{l}\text { Inter-item } \\
\text { correlation }\end{array}$ \\
\hline \multirow[t]{11}{*}{ Northern region } & \multirow[t]{2}{*}{ Factor 1: Escape } & - & - & 3.293 & 0.65 & 0.28 \\
\hline & & To relax & 0.837 & - & - & - \\
\hline & \multirow[t]{3}{*}{ Factor 2: Exploration } & - & - & 3.509 & 0.76 & 0.61 \\
\hline & & To explore a new destination & 0.626 & - & - & - \\
\hline & & To spend time with my friends & 0.817 & - & - & - \\
\hline & \multirow{4}{*}{$\begin{array}{l}\text { Factor 3: Education and } \\
\text { spiritual fulfilment }\end{array}$} & $\begin{array}{l}\text { Primarily for educational reasons (to learn things, } \\
\text { increase my knowledge) }\end{array}$ & 0.822 & - & - & - \\
\hline & & It is a spiritual experience & 0.786 & - & - & - \\
\hline & & I am loyal to the Park & 0.569 & - & - & - \\
\hline & & For the benefit of my children & 0.433 & - & - & - \\
\hline & \multirow{2}{*}{$\begin{array}{l}\text { Factor 4: Value and } \\
\text { amenities }\end{array}$} & - & - & 2.860 & 0.60 & 0.31 \\
\hline & & It is value for money & 0.879 & - & - & - \\
\hline \multirow[t]{13}{*}{ Southern region } & \multirow[t]{3}{*}{ Factor 1: Escape } & - & - & 3.420 & 0.71 & 0.37 \\
\hline & & To relax & 0.827 & - & - & - \\
\hline & & To get away from my routine & 0.740 & - & - & - \\
\hline & \multirow{4}{*}{$\begin{array}{l}\text { Factor 2: Group togetherness } \\
\text { and exploration }\end{array}$} & - & - & 3.177 & 0.61 & 0.35 \\
\hline & & To spend time with my friends & 0.780 & - & - & - \\
\hline & & To explore a new destination & 0.755 & - & - & - \\
\hline & & For the benefit of my children & 0.575 & - & - & - \\
\hline & \multirow{5}{*}{$\begin{array}{l}\text { Factor 3: Photography and } \\
\text { spiritual fulfilment }\end{array}$} & - & - & 4.027 & 0.68 & 0.43 \\
\hline & & To photograph animals and plants & 0.761 & - & - & - \\
\hline & & It is a spiritual experience & 0.747 & - & - & - \\
\hline & & I am loyal to the Park & 0.745 & - & - & - \\
\hline & & $\begin{array}{l}\text { Primarily for educational reasons (to learn things, } \\
\text { increase my knowledge) }\end{array}$ & 0.507 & - & - & - \\
\hline & $\begin{array}{l}\text { Factor 4: Value and } \\
\text { amenities }\end{array}$ & - & - & 3.506 & 0.77 & 0.63 \\
\hline
\end{tabular}

both cases, Bartlett's test of sphericity also reached statistical significance $(p<0.001)$, supporting the factorability of the correlation matrix (Pallant 2007:197).

As Table 2 shows, the following reasons for visiting the northern region of the Park were identified: 'Escape' (Factor 1), 'Exploration' (Factor 2), 'Education' (Factor 3) and 'Value and amenities' (Factor 4). With a mean value of 4.391, 'Education' was found to be the most important motive for travelling to the northern region, followed by 'Exploration' (3.509) and 'Escape' (3.293). 'Value and amenities' (2.860) was rated the least important motive. For the southern region, the motives and the grouping of the items and their importance were different. 'Escape' (Factor 1), 'Group togetherness and exploration' (Factor 2), 'Photography and spiritual fulfilment' (Factor 3) and 'Value and amenities' (Factor 4) were identified as the reasons for travelling to this part of the Park. 'Photography and spiritual fulfilment' (4.027) was rated as the most important motive, followed by 'Value and amenities' (3.506), 'Escape' (3.420) and 'Group togetherness and exploration' (3.177). It is clear from these results that the tourists in this sample visited the two areas of the Park for somewhat different reasons and that the characteristics of the two areas influence these motives. 


\section{Poisson and negative binomial regression analyses}

As Table 3 shows, the dummy variables (socio-demographic and behavioural variables, as well as the travel motives indicated in Table 2) for both the northern and southern regions were coded 1 and 0 to be included in the Poisson regression and the negative binomial regression analyses.

\section{Northern region}

A Poisson regression model was performed with all the independent variables indicated in Table 3, after which a stepwise selection procedure was carried out to decrease the number of variables. The null hypothesis was that the Poisson regression model provided an adequate fit to the data. The residual deviance is a measure of how much the data deviates from the model, so the larger the residual deviance is, the worse the fit. The residual deviance here was 176.55 , to be compared with a chi-square distribution with 166 degrees of freedom. The $p$-value was 0.274 , which

TABLE 3: Relationship between variables and respondents' length of stay.

\begin{tabular}{|c|c|c|}
\hline Category & Variable (topic of question) & Coding \\
\hline \multirow[t]{7}{*}{ Socio-economic } & Home language & Afrikaans $=1 ;$ Other $=0$ \\
\hline & $\begin{array}{l}\text { Are children accompanying } \\
\text { you? }\end{array}$ & $\mathrm{Yes}=1 ; \mathrm{No}=0$ \\
\hline & Most common marital status & Married $=1 ;$ Other $=0$ \\
\hline & $\begin{array}{l}\text { National respondents' province } \\
\text { of origin }\end{array}$ & $\begin{array}{l}\text { Gauteng }=1 ; \text { Other }=0 \\
\text { Mpumalanga }=1 ; \text { Other }=0\end{array}$ \\
\hline & Highest level of education & $\begin{array}{l}\text { High level of education = } 1 \text {; } \\
\text { Other = } 0\end{array}$ \\
\hline & Annual gross income & High income $=1$; Other $=0$ \\
\hline & Mode of transport to the Park & $\begin{array}{l}4 \times 4=1 ; \text { Other }=0 \\
\text { Sedan }=1 ; \text { Other }=0\end{array}$ \\
\hline \multirow[t]{9}{*}{ Behavioural } & Total spending per group & Open question \\
\hline & Group size & Open question \\
\hline & Number of people paying for & Open question \\
\hline & Wild Card holder & Yes $=1 ; \mathrm{No}=0$ \\
\hline & $\begin{array}{l}\text { Recommend park to friends } \\
\text { or family }\end{array}$ & Yes $=1 ;$ No $=0$ \\
\hline & $\begin{array}{l}\text { When decision was made to } \\
\text { visit the Park }\end{array}$ & Long in advance $=1 ;$ Other $=0$ \\
\hline & $\begin{array}{l}\text { Importance of the role of the } \\
\text { Big Five }\end{array}$ & $\begin{array}{l}\text { Important to Extremely } \\
\text { important }=1 ; \text { Other }=0\end{array}$ \\
\hline & Value of the Big Five & $\begin{array}{l}\text { Lion }=1 ; \text { Other }=0 \\
\text { Leopard }=1 ; \text { Other }=0 \\
\text { Rhino }=1 ; \text { Other }=0 \\
\text { Buffalo = } 1 ; \text { Other }=0 \\
\text { Elephant }=1 ; \text { Other }=0\end{array}$ \\
\hline & $\begin{array}{l}\text { Member of a conservation } \\
\text { organisation }\end{array}$ & Yes $=1 ; \mathrm{No}=0$ \\
\hline
\end{tabular}

TABLE 4: Results of the stepwise Poisson regression analysis.

\begin{tabular}{|c|c|c|c|c|}
\hline Category & Estimate & $\begin{array}{l}\text { Standard } \\
\text { error }\end{array}$ & $z$-value & $\operatorname{Pr}(>|z|)$ \\
\hline Intercept & 0.938 & 0.162 & 5.797 & 0.000 \\
\hline Travelling from Gauteng & -0.144 & 0.063 & -2.269 & $0.023 *$ \\
\hline Total spending & 0.000 & 0.000 & 3.116 & $0.002 *$ \\
\hline Wild Card & 0.537 & 0.104 & 5.182 & $0.043^{*}$ \\
\hline $\begin{array}{l}\text { Decision to visit made: Long in } \\
\text { advance }\end{array}$ & 0.175 & 0.086 & 2.028 & $0.043^{*}$ \\
\hline $\begin{array}{l}\text { Importance of the Big Five: } \\
\text { 'Important' to 'Extremely important' }\end{array}$ & 0.099 & 0.062 & 1.577 & 0.115 \\
\hline Lion & 0.277 & 0.107 & 2.589 & $0.010^{*}$ \\
\hline Leopard & 0.215 & 0.104 & 2.071 & $0.038^{*}$ \\
\hline Money for conservation: Yes & -0.184 & 0.072 & -2.552 & $0.011 *$ \\
\hline
\end{tabular}

$*$, Indicates significance at the $5 \%$ level was large enough that the null hypothesis did not have to be rejected. The model therefore appeared to be adequate.

As shown in Table 4, Gauteng as a province of origin ( $p=0.023)$, total spending $(p=0.002)$, decision to visit made long in advance $(p=0.042)$, being a Wild Card holder $(p=0.004)$, lion and leopard as 'must-see' Big Five animals (respectively $p=0.010$ and $p=0.034$ ) and donating money for conservation $(p=0.010)$ had a statistical significant influence on length of stay. With regard to socio-demographic determinants, based on the signs of the coefficients, a person coming from Gauteng would have a predicted stay at the Park 0.866 times shorter than that of the person not coming from this province. Therefore, coming from Gauteng decreased the length of stay when controlling for the other variables. The reason for this could be that, for the tourists travelling from this province, the Park is close and they can therefore travel to the Park more often and, consequently, do not have to stay long in the Park. Tourists with a higher average spending per trip tended to have a longer length of stay. These tourists would have a predicted stay at the Park 1.000 times longer than those with a lower spending per trip. These results validated Hypothesis 1 that stated that the length of stay is determined by individual socio-demographic characteristics.

With regard to behavioural determinants, tourists who made their decision to travel to the Park well in advance would have a predicted stay 1.191 times longer than that of the person who made a spontaneous decision. In addition, tourists who had a Wild Card would have a predicted stay at the Park 1.711 times longer than that of a person who did not have a Wild Card. Having a loyalty card therefore increased the length of stay when controlling for other variables, validating Hypothesis 2 that individual behavioural characteristics influence length of stay.

With regard to the popularity of the Big Five, tourists who most wanted to see lion and leopard would have predicted stays 1.314 and 1.240 times longer, respectively, than those who did not want to see these animals. This could be because the Park is synonymous with the lion, its image being visible in the Park's logo and used extensively in marketing and branding. Leopards are rarely sighted - this is the Big Five animal that most often eludes visitors. This makes them sought-after and visitors perhaps stay longer to increase their chances of seeing one. Another reason may be that June and July (the winter months) are the prime gameviewing time in the Park. Visitors who donated money for conservation causes tended to stay fewer days at the Park and would have a predicted stay 0.832 shorter than that of a person who did not support these causes. Therefore, making the decision to travel well in advance and wanting to see lion and leopard increased the length of stay at the Park when controlling for other variables, whilst donating money for conservation decreased the length of stay. Regarding the Big Five as important to extremely important $(p=0.114)$ was not statistically significant. This determinant 
TABLE 5: Results of the negative binomial regression analysis.

\begin{tabular}{lllll}
\hline Category & Estimate & $\begin{array}{l}\text { Standard } z \text {-value } \\
\text { error }\end{array}$ & $\operatorname{Pr}(>|z|)$ \\
\hline Intercept & 1.104 & 0.218 & 5.060 & 0.000 \\
Afrikaans & -0.175 & 0.083 & -2.095 & $0.036^{*}$ \\
Number of people paying for & -0.071 & 0.025 & -2.850 & $0.004^{*}$ \\
Country of residence: South Africa & 0.244 & 0.167 & 1.458 & 0.145 \\
Decision to visit made: Long in advance & 0.243 & 0.089 & 2.740 & $0.006^{*}$ \\
Mode of transport: 4×4 & -0.137 & 0.083 & -1.647 & 0.100 \\
Mode of transport: Sedan & -0.281 & 0.099 & -2.828 & $0.005^{*}$ \\
Total spending & 0.000 & 0.000 & 4.318 & $0.000^{*}$ \\
Wild Card & 0.717 & 0.105 & 6.849 & $0.000^{*}$ \\
Lion & -0.132 & 0.079 & -1.658 & 0.097 \\
Leopard & -0.115 & 0.080 & -1.438 & 0.150 \\
Motive: Escape & 0.082 & 0.041 & 2.025 & $0.043^{*}$ \\
\hline
\end{tabular}

*, Indicates significance at the $5 \%$ level

did, however, still have an important effect on length of stay. Tourists who considered seeing the Big Five to be very important would have a predicted stay 1.103 times longer than those for whom this was less important. These results supported Hypothesis 3 that destination characteristics also influenced length of stay.

\section{Southern region}

Here the residual deviance was 218.89 , to be compared with a chi-square distribution with 222 degrees of freedom. The $p$-value was 0.546 , which was large enough that the null hypothesis did not have to be rejected. The model therefore appeared to be adequate.

As Table 5 shows, Afrikaans as home language $(p=0.036)$, number of people paying for $(p=0.004)$, decision to visit made long in advance $(p=0.006)$, sedan as mode of transport $(p=0.004)$, total spending $(p=0.000)$, being a Wild Card holder $(p=0.000)$ and being motivated by 'Escape' $(p=0.043)$ had a statistically significant influence on length of stay. With regard to socio-demographic determinants, Afrikaansspeaking tourists and those who used a sedan to travel to the Park would have a predicted stay respectively 0.840 and 0.755 times shorter than that of either English-speaking or foreign language tourists and tourists who used other modes of transport to travel to the Park, validating Hypothesis 1.

With regard to behavioural determinants, travelling with a larger group had a negative influence on length of stay and visitors who travelled in larger groups to the Park would have a predicted stay 0.932 shorter than that of tourists who travelled in smaller groups. Here, the result was similar to that obtained for the northern region: making the decision to travel to the Park well in advance had a positive influence on length of stay and these tourists would have a predicted stay 1.275 longer than that of the tourists who made a spontaneous decision. Tourists motivated more by the motive 'Escape' also tended to stay longer at the Park (1.088 times longer). In addition, those with a higher total average spending and who were Wild Card holders tended to stay longer at the Park (respectively 1.000 and 2.048 times longer). These results confirmed Hypothesis 2.
The other variables did not have a statistically significant influence on length of stay; however, tourists who were local residents from South Africa tended to stay 1.276 times longer than tourists travelling from outside the borders of the country. Like the tourists who travelled with a sedan to the Park, those who used a $4 \times 4$ to travel tended to have a shorter length of stay (0.872 times shorter than that of visitors who used other modes of transport). Contradicting the results obtained for the northern region, wanting to see a lion or leopard had a negative influence on length of stay (respectively 0.877 and 0.892 shorter than the stay of tourists who did not particularly want to see them), rejecting Hypothesis 3 that destination characteristics influenced length of stay.

\section{Trustworthiness}

The following steps, as proposed by Field (2003) as well as Zikmund et al. (2010) were followed to design and validate the questionnaire as well as the results:

- Content validity: an in-depth literature analysis was performed to identify the relevant motivational factors for travelling to the Kruger National Park. The questionnaire was based on Van der Merwe and Saayman (2008), Saayman and Saayman (2009) and Kruger and Saayman (2010).

- Face validity: statistical consultation services advised on the formulation of the statements as well as the measuring scales used. The park manager also gave their opinion on the included items and whether it captured the essence of the study.

- Construct validity: factor analyses were performed on the motivational factors for travelling to the northern and southern region of the park in order to determine the degree to which the statements measures what it claims, or purports, to be measuring (please see the 'Statistical analysis' and 'Factor analysis' sections for more detail).

- Reliability: to test the reliability of the identified factors, reliability coefficients (Cronbach's alpha) and interitem correlations were calculated (please also see the 'Statistical analysis' and 'Factor analysis' sections for more detail).

\section{Discussion}

This article identified the determinants of length of stay for tourists at a nature-based destination in South Africa, namely the Kruger National Park. The size, nature and characteristics of this Park made it possible for the first time to differentiate between determinants of length of stay for different regions, namely the northern and southern regions of the Kruger Park. The results revealed clear differences between the determinants of length of stay for the two regions. The general conclusion was that tourists travelling to the northern region with a higher total average spending, who made their decision to visit the Kruger Park long in 
advance, who were Wild Card holders and who were keen to see lion and leopard whilst on holiday were likely to stay longer in this region of the Park.

A different set of determinants were found to affect the length of stay in the southern region: here, Afrikaansspeaking tourists who travelled in smaller groups, with a higher total average spending, who made their decision to travel to the Park long in advance, who were Wild Card holders and who were motivated by the need to escape, were likely to stay longer. This study corroborates the finding by Alegre and Pou (2006) that travelling in larger groups has an inverse influence on length of stay: the larger the group, the shorter the stay. In addition, the results support the finding by Gokovali et al. (2007) that tourists who spend more stay longer. However, it contradicts the findings by Menezes and Moniz (2006) and Menezes et al. (2008) that tourists who travel shorter distances stay longer than those who travel further.

The results supported all three of the study's hypotheses. Firstly, for both the northern and southern regions of the Park, tourists' individual socio-demographic characteristics (total spending, province of origin, group size and home language) influenced the length of stay, validating Hypothesis 1. The socio-demographic determinants were, however, different for the two regions. Secondly, behavioural variables (decision-making, mode of transport, being loyalty members, desire to see the Big Five and not donating to conservation causes) explained the length of stay, validating Hypothesis 2. Here again the determinants for the two regions were different; however, behavioural characteristics seemed to have a stronger influence on length of stay in both regions than socio-demographic characteristics. Thirdly, the length of stay was also determined by the characteristics of the two regions (the two destinations), such as the different likelihood of seeing the Big Five, validating Hypothesis 3.

It was clear from the results that the length of stay was specific to each of the two tourism destinations, supporting previous research by Alegre and Pou (2006), Alegre, Mateo and Pou (2011), Barros and Machado (2010), Barros et al. (2010), Gokovali et al. (2007), Martinez-Garcia and Raya (2008), Menezes and Moniz (2006), Menezes et al. (2008) and Peypoch et al. (2011). The determinants of length of stay are also more internal rather than external factors (see Figure 2). However, the study makes a further contribution: on the basis of its findings for the two regions, it cautions marketers to approach the Park from a regional perspective (i.e. making a distinction between two different parts of the same national park) rather as a whole. This might also apply to other destinations in the world that consist of regions offering different products.

\section{Limitations}

One apparent limitation was that the survey was conducted separately during the winter (northern region) and summer (southern region). The type of visitor differs during these months and future research should perhaps consider conducting a survey in both regions at the same time either during the winter or summer in order to accurately compare results.

\section{Recommendations}

The results of this study provide a clear, focused view of the reasons for tourists' length of stay at the naturebased destination analysed. This method furthermore takes into account that the characteristics of the different regions themselves may influence length of stay. From a methodological point of view, a regional approach is therefore suitable for analysing a destination with multifaceted characteristics, such as the Kruger National Park, where tourists also resemble homogeneous tendencies. As it enables a concise comparison of the effect on length of stay of the same variables in different regions, it should prove valuable to destination marketers, planners and managers, as well as academics. Findings produced by this method will enable them to differentiate between and compare different regions and plan their strategies accordingly to encourage visitors to stay longer.

It is, of course, not possible to control all the determinants influencing length of stay in the Kruger Park. However, it is possible to concentrate on the important ones and to highlight them in advertising and promoting the different regions of the Park. On the basis of the findings of this study, a diversified strategy is recommended. If the Park is to increase tourists' length of stay in the northern region, its marketing campaigns should focus on the Big Five, especially lion and leopard. More information about these animals, their behaviour and preferred terrain should be made available to tourists at the different rest camps and in the game drives and guided walks. This might help to attract longer-staying visitors. To increase length of stay in the southern region, marketing campaigns should focus on people's desire to escape from the routine of their daily lives and emphasise that the Park is the ideal relaxing and breakaway holiday destination. The benefits of the current loyalty card (the Wild Card) should also be marketed more intensively, because this will encourage tourists to stay longer irrespective of which of the two regions they visit.

\section{Conclusion}

In summary, because a combination of socio-demographic and behavioural determinants influences length of stay, and length of stay may differ for different regions of a destination, at a nature-based destination like the Kruger Park a regional analysis is advisable and a diversified marketing strategy will be more likely to increase the average length of stay than an undifferentiated mass strategy. As more research is needed to confirm these findings, it is recommended that a similar method be applied to other nature-based destinations, as well as 'seaand-sun' destinations. 


\section{Acknowledgements Competing interests}

The authors declare that they have no financial or personal relationships that may have inappropriately influenced them in writing this article.

\section{Authors' contributions}

M.K. (North-West University) was the lead author on the article, conceptualised the idea, conducted the survey, analysed the data together with the Statistical Consultation Services at the North-West University and did the final technical editing. M.S. (North-West University) focused on the findings and implications, as well as general flow of the research.

\section{References}

Agresti, A., 2007, An introduction to categorical data analysis, 2nd edn., John Wiley and Sons, Gainesville. http://dx.doi.org/10.1002/0470114754

Alegre, J. \& Pou, L., 2006, 'The length of stay in the demand for tourism', Tourism Management 27(1), 1343-1355. http://dx.doi.org/10.1016/j. tourman.2005.06.012

Alegre, J., Mateo, S. \& Pou, L., 2011, 'A latent class approach to tourists' length of stay', Tourism Management 32(3), 555-563.

Barros, C.P. \& Machado, L.P., 2010, 'The length of stay in tourism', Annals of Tourism Research 1(1), 1-15.

Barros, C.P., Butler, R. \& Correia, A., 2010, 'The length of stay of golf tourism: A survival analysis', Tourism Management 31(1), 13-21. http://dx.doi.org/10.1016/j. tourman.2009.02.010

Bartlett, M.S., 1954, 'A note on the multiplying factors for various chi-square approximations', Journal of the Royal Statistical Society 16(Series B), 296-298.

Briggs, S.R. \& Cheek, J.M., 1986, 'The role of factor analysis in the development and evaluation of personality scales', Journal of Personality 54(1), 106-149.

Cannon, T.F. \& Ford, J., 2002, 'Relationship of demographic and trip characteristics to visitor spending: An analysis of sports travel visitors over time', Tourism Economics 8(3), 263-271. http://dx.doi.org/10.5367/000000002101298106

Clark, L.A. \& Watson, D., 1995, 'Constructing validity: Basic issues in objective scale development', Psychological Assessment 7(3), 309-319. http://dx.doi. org/10.1037/1040-3590.7.3.309

Cook, R.A., Yale, L.J. \& Marqua, J.J., 2010, Tourism: The business of travel, 4th edn., Pearson Education, Upper Saddle River.

Dancey, C.P. \& Reidy, J., 2004, Statistics without maths for psychology: Using SPSS for Windows, 3rd edn., Prentice Hall, New York.

Davies, L.E., 2002, 'Consumers' expenditure on sport in the UK: Increased spending or underestimation?', Managing Leisure 7(2), 83-102. http://dx.doi. spending or underestimation?', $M$,
org/10.1080/13606710210137237

Decrop, A. \& Snelders, D., 2004, 'Planning the summer vacation: An adaptable process', Annals of Tourism Research 31(4), 1008-1030. http://dx.doi. org/10.1016/j.annals.2004.03.004

Downward, P. \& Lumsdon, L., 2004, 'Tourism transport and visitor spending: A study in the New York Moors National Park, UK', Journal of Travel Research 42(4), 415420. http://dx.doi.org/10.1177/0047287504263038

Du Plessis, L., Saayman, M. \& Erasmus, L.J.J., 2010, 'A marketing and management analysis of overnight and day visitors to the Kruger National Park December analysis of overnight and day visitors to the Kruger National Park December
$2009 / 10$, unpublished report for the Institute for Tourism and Leisure Studies, $2009 / 10$, unpublished report for the Instity,
North-West University, Potchefstroom.

Field, A., 2005, Discovering statistics using SPSS, SAGE, Thousand Oaks.

Gokovali, U., Bahar, O. \& Kozak, M., 2007, 'Determinants of length of stay: A practical use of survival analysis', Tourism Management 28(1), 736-746. http://dx.doi. org/10.1016/j.tourman.2006.05.004

Holden, A., 2008, Environment and tourism, 2nd edn., Routledge, London.

Israel, G.D., 2009, Determining sample size, viewed 12 July 2010, from http://www. edis.ifas.ufl.edu/pdffiles/pd/pd00600.pdf

Jang, S., Bai, B., Hong, G. \& O'Leary, J.T, 2004, 'Understanding travel expenditure patterns: A study of Japanese pleasure travelers to the United States by income level', Tourism Management 25(3), 331-341. http://dx.doi.org/10.1016/S02615177(03)00141-9

Kaiser, H., 1970, 'A second generation little jiffy', Psychometrika 35(4), 401-415.

Kaiser, H., 1974, 'An index of factorial simplicity', Psychometrika 39(1), 31-36.

Kozak, M., 2001, 'Comparative assessment of visitors' satisfaction with destinations across two nationalities', Tourism Management 22(4), 391-401. http://dx.doi. org/10.1016/S0261-5177(00)00064-9

Kozak, M., Gokovali, U. \& Bahar, O., 2008, 'Estimating the determinants of tourist spending: A comparison of four models', Tourism Analysis 13(2), 143-155.
Kruger, M., Saayman, M. \& Saayman, A., 2010, 'Expenditure-based segmentation of visitors to Tsitsikamma National Park', Acta Commercii 10(1), 137-149.

Kruger, M. \& Saayman, M., 2010, 'Travel motivation of tourists to Kruger and Tsitsikamma National Parks: A comparative study', South African Journal of Wildlife Research 40(1), 93-102.

Kruger, M., Saayman, M. \& Manners, B., 2012, 'Determinants of visitor expenditure at the Tsitsikamma National Park', Journal of Economics and Financial Science 5(1), 11-30.

Krugerpark.com, 2011, Full map of the Kruger National Park, viewed 07 August 2013, from http://www.krugerpark.com/maps/full-map-of-the-kruger-national-park/

Legohérel, P., 1998, 'Toward a market segmentation of the tourism trade: Expenditure levels and consumer behaviour instability', Journal of Travel and Tourism Marketing 7(3), 19-39. http://dx.doi.org/10.1300/J073v07n03_02

Leones, J., Colby, B. \& Crandall, K., 1998, 'Tracking expenditures of the elusive nature tourists to south-eastern Arizona', Journal of Travel Research 36, 56-64. http:// dx.doi.org/10.1177/004728759803600306

Mabunda, D.M., Pienaar, D.J. \& Verhoff, J., 2003, 'The Kruger National Park: A century of management and research', in J.T. du Toit, K.H. Rogers \& H.C. Biggs (eds.), The Kruger experience: Ecology and management of savanna heterogeneity, pp. 3-21, Island Press, Washington, DC.
Int

Mabunda, D.M. \& Wilson, D., 2009, 'Commercialisation of national parks: South Africa's Kruger National Park as an example', in J. Saarinen, F. Becker, H. Manwa \& D. Wilson (eds.), Sustainable tourism in southern Africa, pp. 116-133, Channel View Publications, Bristol.

Machado, L.P., 2010, 'Does destination image influence the length of stay in a tourism destination', Tourism Economics 16(2), 443-456. http://dx.doi. org/10.5367/000000010791305554

Malhotra, N.K., 2007, Marketing research: An applied orientation, 5th edn., Prentice Hall, Upper Saddle River.

Martinez-Garcia, E. \& Raya, J.M., 2008, 'Length of stay for low-cost tourism', Tourism Management 29(1), 1064-1075. http://dx.doi.org/10.1016/j.tourman.2008.02.011

Mehmetoglu, M., 2007, 'Nature-based tourists: The relationship between their trip expenditures and activities', Journal of Sustainable Tourism 15(2), 200-215. http:// dx.doi.org/10.2167/jost642.0

Menezes, A.G. \& Moniz, A., 2006, 'Determinants of length of stay: A parametric survival analysis', working paper no. 19/2006, Centro de Estudos de Economia Aplica do Atlântico, viewed 25 March 2014, from https://repositorio.uac.pt/ handle/10400.3/1152

Menezes, A.G., Moniz, A. \& Viera, J.C., 2008, 'The determinants of length of stay of tourists in the Azores', Tourism Economics 14, 205-222.

Mok, C. \& Iverson, T.J., 2000, 'Expenditure-based segmentation: Taiwanese tourists to Guam', Journal of Travel Research 16(1), 1-4.

Mules, T., 1998, 'Decomposition of Australian tourist expenditure', Tourism Management 19(30), 267-271. http://dx.doi.org/10.1016/S0261-5177(98)00014-4

Oppermann, M., 1995, 'Travel life cycle', Annals of Tourism Research 22(3), 535-552. http://dx.doi.org/10.1016/0160-7383(95)00004-P

Oppermann, M., 1997, 'First-time and repeat visitors to New Zealand', Tourism Management 18(1), 177-181. http://dx.doi.org/10.1016/S0261-5177(96)00119-7

Pallant, J., 2007, SPSS survival manual: A step-by-step guide to data analysis using SPSS version 15, McGraw-Hill, New York.

Peypoch, N., Randriamboarison, R., Rasoamananjara, F. \& Solonandrasana, B., 2011, 'The length of stay of tourists in Madagascar', Tourism Management 1(1), 1-6.

Ritchie, J.R.B. \& Crouch, G.I., 2003, The competitive destination, CABI Publishing, Cambridge.

Saarinen, J., 2005, 'Tourism in the northern wildernesses: Wilderness discourses and the development of nature-based tourism in northern Finland', in C.M. Hall \& S. Boyd (eds.), Nature-based tourism in peripheral areas: Development or disaster? pp. 36-49, Channel View Publications, Clevedon.

Saayman, M. \& Saayman, A., 2008, 'Estimating the economic contribution of visitor spending in the Kruger National Park to the regional economy', Journal of Sustainable Tourism 14(1), 67-81. http://dx.doi.org/10.1080/09669580608668592

Saayman, A. \& Saayman, M., 1997, 'Die ekonomiese impak van toerisme op die SuidAfrikaanse ekonomie', South African Journal of Economic Management Sciences 21, 162-174.

Saayman, M. \& Saayman, A., 2009, 'Why travel motivation and socio-demographics matter in managing a national park', Koedoe $51(1), 9$ pages.

SA Venues, 2013, Kruger National Park, viewed 07 August 2013, from http://www.savenues.com/game-reserves/mpl_kruger.htm

Seaton, A.V. \& Palmer, C., 1997, 'Understanding VFR tourism behaviour: The first five years of the United Kingdom tourism survey', Tourism Management 1(6), 345-355. http://dx.doi.org/10.1016/S0261-5177(97)00033-2

Smit, I.P.J., Grant, C.C. \& Whyte, I.J., 2007, 'Landscape-scale sexual segregation in the dry season distribution and resource utilisation of elephant in Kruger National Park, South Africa', Diversity and Distributions 13, 225-236. http://dx.doi.org/10.1111/ j.1472-4642.2007.00318.x

South African National Parks, 2009, Annual report 2008-2009, viewed 15 February 2010, from http://www.sanparks.org/about/annual/2009.pdf

Spotts, D.M. \& Mahoney, E.M., 1991, 'Segmenting visitors in a destination region based on the volume of their expenditure', Journal of Travel Research 29(4), 24-31. on the volume of their expenditure', Journal of
$\mathrm{http} / / / \mathrm{dx}$.doi.org/10.1177/004728759102900405

SPSS version 20, 2013, computer software, IBM, Chicago.

Stevens, J., 2010, 'Number of visitors to SANParks', 12 April, JoepS@sanparks.org 
Steyn, H.S., 2000, 'Practical significance of the difference in means', South African Journal of Industrial Psychology 26(3), 1-3.

Sung, H.H., Morrison, A.M., Hong, G.S. \& O'Leary, J.T., 2001, 'The effects of household and trip characteristics on trip types: A consumer behavioural approach for segmenting the US domestic leisure travel market', Journal of Hospitality and Tourism Research 25(1), 46-68, http://dx.doi. org/10.1177/109634800102500105

Taylor, D.T., Fletcher, R.R. \& Clabaugh, T., 1993, 'A comparison of characteristics, regional expenditures and economic impact of visitors to historical sites with other recreational visitors', Journal of Travel Research 32(1), 30-35. http://dx.doi. org/10.1177/004728759303200105

Thrane, C. \& Farstad, E., 2009, 'Domestic tourism expenditures: The non-linear effects of length of stay and travel party size', Tourism Management 1(1), 1-7.
Tinker, A. \& Tinker, L., 2011, 'Kruger National Park: Guide and map', Andy Tinker Photography, Witrivier, Mpumalanga.

Van Der Merwe, P. \& Saayman, M., 2008, 'Travel motivations of tourists visiting Kruger National Park', Koedoe 50(1), 154-159.

Van Der Merwe, P., Saayman, M. \& Krugell, W., 2007, 'The determinants of spending by biltong hunters', South African Journal of Economics and Management Science 10(2), 184-194.

Uysal, Y., McDonald, C.D. \& Martin, B.S., 1994, 'Australian visitors to US National Parks and natural areas', International Journal of Contemporary Hospitality Management 6(3), 18-24. http://dx.doi.org/10.1108/09596119410059209

Zikmund, W.G., Babin, B.J., Carr, J.C. \& Griffin, M., 2010, Business research methods, 8th edn., South Western Cencage Learning, Mason. 